\title{
Assessment of the attributes of Primary Health Care with women of reproductive age
}

\author{
Avaliação dos atributos da Atenção Primária a Saúde com mulheres em idade reprodutiva \\ Evaluación de los atributos de la Atención Primaria de Salud con mujeres en edad fértil
}

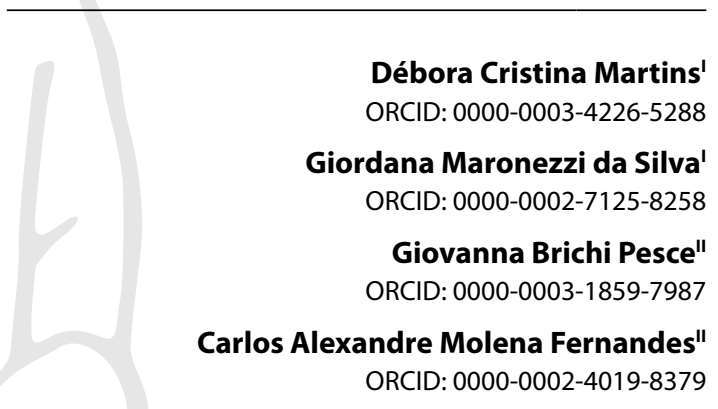

'Universidade Estadual de Maringá. Maringá, Paraná, Brazil. "Universidade Estadual do Paraná. Paranavaí, Paraná, Brazil.

How to cite this article: Martins DC, Silva GM, Pesce GB, Fernandes CAM. Assessment of the attributes of Primary Health Care with women of reproductive age. Rev Bras Enferm. 2022;75(3):e20210015. https://doi.org/10.1590/0034-7167-2021-0015

Corresponding author: Débora Cristina Martins E-mail: martinsdebora344@gmail.com

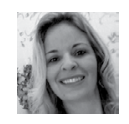

EDITOR IN CHIEF: Antonio José de Almeida Filho ASSOCIATE EDITOR: Fátima Helena Espírito Santo

Submission: 01-28-2021 Approval: 07-06-2021

\begin{abstract}
Objectives: to evaluate the quality of Primary Health Care attributes according to the characterization and perspective of women of reproductive age. Methods: descriptive, quantitative, cross-sectional study, with 397 women of reproductive age from six municipalities in the 16th Health Region of the state of Paraná, with variables for sociodemographic characterization and the Primary Care Assessment Tool (PCATool). Results: mean age, 30.43 years old, most were married, $70.2 \%$ worked outside the home and $55.5 \%$ had completed high school. The highest average score of the eight domains evaluated was "Family Guidance" and "Coordination - Integration of Care", with averages of 5.86 and 4.89. Domains "Integrality - Services Provided" and "Community Orientation" had lower averages (3.32 and 3.76). Conclusions: the study allowed tracing the characterization of the participants and identifying that the attributes of Primary Care are unsatisfactory, making it necessary to expand access to the services offered and to qualify the comprehensive care for women's health.

Descriptors: Women's Health; Primary Health Care; Health Assessment; Women's Health Services; Comprehensive Health Care.
\end{abstract}

\section{RESUMO}

Objetivos: avaliar a qualidade dos atributos da Atenção Primária à Saúde de acordo com a caracterização e perspectiva de mulheres em idade reprodutiva. Métodos: pesquisa descritiva, quantitativa, de delineamento transversal, com 397 mulheres em idade reprodutiva de seis municípios da $16^{a}$ Regional de Saúde do estado do Paraná, com variáveis para caracterização sociodemográfica e o Instrumento Primary Care Assessment Tool (PCATool). Resultados: média da idade, 30,43 anos, maioria era casada, $70,2 \%$ trabalhavam fora e $55,5 \%$ tinham ensino médio completo. O maior escore médio dos oito domínios avaliados foi "Orientação Familiar" e "Coordenação - Integração de Cuidados", com médias 5,86 e 4,89. Domínios "Integralidade - Serviços Prestados" e "Orientação Comunitária" tiveram menores médias $(3,32$ e 3,76). Conclusões: o estudo permitiu traçar a caracterização das participantes e identificar que os atributos da Atenção Primária estão insatisfatórios, sendo necessário ampliar o acesso aos serviços ofertados e qualificar o cuidado integral à saúde da mulher. Descritores: Saúde da Mulher; Atenção Primária à Saúde; Avaliação em Saúde; Serviços de Saúde da Mulher; Assistência Integral à Saúde.

\section{RESUMEN}

Objetivos: evaluar la calidad de atributos de la Atención Primaria de Salud conforme la caracterización y perspectiva de mujeres en edad fértil. Métodos: investigación descriptiva, cuantitativa, de delineamento transversal, con 397 mujeres en edad fértil de seis municipios de la $16^{\text {a }}$ Regional de Salud del estado de Paraná, con variables para caracterización sociodemográfica y el Instrumento Primary Care Assessment Tool (PCATool). Resultados: mediana de edad, 30,43 años, mayoría era casada, $70,2 \%$ trabajaban fuera y $55,5 \%$ hicieron bachillerato completo. El mayor escore mediano de los ocho dominios evaluados fue "Orientación Familiar" y "Coordinación - Integración de Cuidados", con medianas 5,86 y 4,89. Dominios "Integralidad - Servicios Prestados" $y$ "Orientación Comunitaria"tuvieron menores medianas $(3,32$ y 3,76$)$. Conclusiones: el estudio permitió trazar la caracterización de las participantes e identificar que los atributos de Atención Primaria están insatisfactorios, siendo necesario ampliar el acceso a servicios ofertados y calificar el cuidado integral de salud para mujer. Descriptores: Salud de la Mujer; Atención Primaria de Salud; Evaluación en Salud; Servicios de Salud para Mujeres; Atención Integral de Salud. 


\section{INTRODUCTION}

Primary Health Care (PHC) is structured as a strategy for organizing and reorganizing health systems in their first level of care, addressing the most common problems in the population. Among the services offered are disease prevention, cure, and rehabilitation to offer health and well-being to users of the Unified Health System ${ }^{(1)}$.

PHC stands out for different models, among which Programmatic Actions in Health stand out. It also organizes and rationalizes the resources destined to the promotion, maintenance, and improvement of health, being a model of change in clinical-care practice for health professionals, individuals and community ${ }^{(2)}$.

The Family Health Strategy (FHS) in Brazil has priority PHC in expansion and consolidation as the health promotion and disease prevention that are offered to individuals and society through the reorientation of the work process. Such actions have the potential to increase the level of resolution, in addition to the cost-effectiveness related to the health services offered to the population. 2 It is important to highlight that the FHS aims to reformulate the care model to implement the Unified Health System (SUS)(3).

In the routine of $\mathrm{PHC}$ services, the presence of young women ${ }^{(4)}$, of reproductive age, is evident. Generally, these services are for medical consultations and curative treatments, in addition to gynecological consultations, prenatal care, educational and preventive actions aimed at women's health. It is important to note that women also accompany their children and other family members in health services ${ }^{(5)}$. However, it is believed that, according to public health policies, there is still insufficient resolving power related to health problems in this population and lack of actions effective by the health teams inserted in the $\mathrm{PHC}^{(6)}$.

Regarding these weaknesses, it is necessary to emphasize that women's health care must be comprehensive, extending to maternal and childcare and certain problems in the reproductive phase and encompassing the entire life cycle in its different phases. Thus, it is essential to study women of reproductive age, considering that they are young and susceptible to disease prevention. It is very important that health professionals know how to take advantage of the various opportunities in which women are in PHC seeking essential care and know how to implement it universally, longitudinally, comprehensively, and comprehensively, which is still a major challenge in $\mathrm{PHC}^{(7)}$.

Considering the gaps in the demand for care, it is observed that they refer to the diagnosis and treatment of diseases in PHC for women of reproductive age ${ }^{(8)}$. It is worth emphasizing the need for comprehensive health care for these women and the expansion of network services in the PHC, with the availability of trained professionals, physical space with adequate and sufficient equipment ${ }^{(9)}$.

However, to meet this demand, it is essential to consider the attributes of PHC to offer resolute and quality services. It is noteworthy that there are still many challenges related to coping with the changes arising from the social, demographic and morbidity and mortality profile in this population ${ }^{(10)}$. It is believed that, with these changes, there have been more exposures to risk factors and an increase in chronic diseases in populations younger, it is important to consider health promotion and disease prevention actions in $\mathrm{PHC}$ and not just diagnosis and treatment ${ }^{(11)}$.

The proposal of comprehensive health for women aims to provide care in all life cycles7, however, in practice, comprehensive care does not yet occur, as the health system has difficulties in assisting women in different specific areas, such as preventing chronic diseases, climacteric, infertility, mental health and occupational health ${ }^{(5-7)}$.

The evaluation in the field of PHC in Brazil has been directed by the Ministry of Health (MS) ${ }^{(12)}$. It has an important performance in the improvement of intervention axes to support the shared decision process, to review professional practices, reorganize the method of work in the different contexts of PHC, manage resources, readjust actions for health promotion and disease prevention and redefine logical objectives with health projects established with the $\mathrm{FHS}^{(3,7)}$.

Thus, when evaluation studies are carried out, it is likely to know the perception of women of reproductive age about the services offered and models of care related to the implemented health care and management practices, so that the PHC acts as coordinator of care and organizer of the network of services offered $^{(4)}$. Thus, there is a need to assess the development of services offered in PHC to respond to these unique demands.

\section{OBJECTIVES}

To assess the quality of Primary Health Care according to the characterization and perspective of women of reproductive age.

\section{METHODS}

The methodology applied to this research is presented in the following sections.

\section{Ethical aspects}

The study was approved by the Standing Committee on Ethics in Research with Human Beings of the State University of Paraná - Unespar, campus of Paranavaí, and complies with all the norms of Resolution $n^{\circ} 466 / 2012$ of the National Health Council of Brazil. For access to women of reproductive age in $\mathrm{PHC}$ health institutions, formal authorization was obtained from the health secretariats of the study municipalities, through an acceptance term signed by the health secretaries. All research participants signed the Free Informed Consent Form (FICF).

\section{Study design, period, and place}

This is a descriptive, evaluative research with a quantitative approach and cross-sectional design, carried out in eight Basic Health Units (BHU), two Health Centers and two Women's Clinics, located in the urban area of six municipalities belonging to the 16th Regional of Health, in the north of the state of Paraná, Brazil, whose care model is the FHS. Data collection took place from July 2019 to September 2020, on the premises of the selected institutions, through interviews conducted individually. The consolidated criteria for this methodology were guided by the STROBE tool. 


\section{Population, inclusion, and exclusion criteria}

The population of 111,658 women of reproductive age from 17 municipalities of the 16th Health Region, in the north of the state of Paraná, was considered, according to data from the Department of Primary Care Information (E-SUS AB). The sample selection aimed to geographically cover the entire region. $A$ double stage, stratified random sampling process was adopted, considering the number of women of reproductive age in each municipality and the size of the municipality (small: up to 10,000 ; medium: between 10,001 and 50,000; large: over 50,001 inhabitants), taking into account logistical feasibility reasons. Thus, after stratifying the municipalities, six municipalities from the 16th RS were drawn.

Subsequently, we proceeded to randomize the sample stratified by number of women of reproductive age in each municipality. The original sample size was determined based on a $50 \%$ prevalence of the outcome, with a guarantee of a sample with the maximum possible population, to control the level of error and confidence. Weighing an alpha of $5 \%$ and a statistical power of $80 \%$, a sample of 397 women was obtained, with an addition of $10 \%$ to cover any losses.

The population of women interviewed in each selected municipality was proportional to the number of women registered in the E-SUS AB and the average number of women assisted in the institutions where the research took place. 431 women were interviewed; seven withdrew from the survey in the middle of the interview for reasons of time, call for appointments and others; and 27 research instruments were discarded due to illegible or incomplete filling. Thus, the final sample totaled 397 women of reproductive age from 18 to 49 years old.

Participants were recruited for the research as they attended the institutions of the selected municipalities to carry out medical consultations, collect preventive exams, prenatal care, and others, from Monday to Friday, in the morning and afternoon. While waiting for care, the researchers received a brief screening, invited them to participate in the research, and the data were collected in rooms or offices available to maintain the privacy of women.

As inclusion criteria, women aged between 18 and 49 years old, who had been previously assisted at least once in the last two years by an FHS team, were eligible for the research. Women of reproductive age who, at the time of the research, did not present good physical health conditions (difficulty in speaking, walking or under the effect of medication) or who had undergone any previous procedure that prevented participation in the study were excluded.

\section{Study protocol}

The research team was composed of students in the last year of the undergraduate Nursing course of a private educational institution, a nurse and two nursing technicians who had no relationship with the services. They were duly trained by the research coordinator to carry out the interviews, with guidelines to seek a welcoming and private environment for women during the research.

For data collection, two instruments were used. The first is considered a clinical record for the characterization of women, with data on age, religion, education, marital status, sociodemographic data, lifestyle, risk behaviors, presence of chronic diseases, gynecological and obstetrical history. The second is the Primary Care Assessment Tool, the Primary Care Assessment Tool (PCATool), used to verify the presence and extent of Primary Health Care (PHC) attributes in health services. Such attributes are classified into "essentials" and "derivatives"(13).

The essential attributes are thus characterized by being related to a Primary Care service aimed at the general population, being the pillars of the Primary Care providers services. These attributes are classified into four axes: First Contact Access, Longitudinality, Integrality and Care Coordination. Derived attributes are Family Orientation and Community Orientation. Derived attributes classify actions in Primary Health Care, expanding their power to interact with individuals and the community in general(13-14).

PCATool consists of 88 alternatives. The answers for each of them consist of the following choices: "certainly yes" (value $=4$ ), "probably yes" (value = 3), "probably not" (value =2), "certainly not" (value = 1) and "I don't know/I don't remember" (value = 9). The average score evaluated for each component is calculated by adding the value of the alternatives divided by the number of alternatives ${ }^{(8,10)}$. Services considered of good quality are those classified with a score of 6.6 or more, with values below 6,6 refer to low quality services in $\mathrm{PHC}^{(13-14)}$.

\section{Analysis of results and statistics}

For statistical analysis, all responses were tabulated with double entry in a database organized in Microsoft Excel software and later analyzed using the $\mathrm{R}$ software (R Development Core Team, 2016), version 3.6.2. To characterize the research participants, a descriptive analysis of the results was performed, obtaining a table with absolute and relative frequency.

For the description of the domain scores and the items of the attributes evaluated negatively, simple arithmetic mean, and standard deviation were used. The final score of each attribute was reached by calculating the average related to the answers of the interviewees, whose cut-off value was $\geq 3$ (which is the value corresponding to 6.6 on a scale from 0 to 10 ), considered as satisfactory, or oriented, i.e., acceptable for APS services. Scores below 6.6 indicate unsatisfactory performance. As for the overall score, the mean was obtained between the components of essential attributes and the components of derived attributes. The value assigned to the scores (E) was considered a standard scale ranging from 0 to 10 , using the following formula:

$$
E=[(\text { escore }-1) \times 10] / 3(10)
$$

\section{RESULTS}

In total, 397 women of reproductive age were interviewed. Almost two thirds (69.2\%) are residents of municipality 1 , which is considered the largest. The others are divided between municipality 2, considered to be medium-sized (9.32\%); and four small municipalities (numbers $3,4,5$ and 6 ) (21.42\%), totaling six municipalities. Regarding age, it is observed that $45.09 \%$ are in the age group from 21 to 30 years old, with the average age being 30.43 years old (Table 1 ). 
Table 1 - Frequency distribution of sociodemographic characteristics of women of reproductive age in six municipalities in the 16th Health Region ( $\mathrm{n}=397)$, northern Paraná state, Brazil, 2020

\begin{tabular}{|c|c|c|}
\hline Variable & $\mathbf{n}$ & $\%$ \\
\hline \multicolumn{3}{|l|}{ City } \\
\hline Municipal 1 & 275 & 69.2 \\
\hline Municipal 2 & 37 & 9.4 \\
\hline Municipal 3 & 26 & 6.6 \\
\hline Municipal 4 & 24 & 6.0 \\
\hline Municipal 5 & 11 & 2.7 \\
\hline Municipal 6 & 24 & 6.0 \\
\hline \multicolumn{3}{|l|}{ Age (years) } \\
\hline from 18 to 20 & 41 & 10.3 \\
\hline from 21 to 30 & 179 & 45.0 \\
\hline from 31 to 40 & 131 & 33.0 \\
\hline 41 to 49 & 46 & 11.5 \\
\hline \multicolumn{3}{|l|}{ Work away } \\
\hline Yes & 239 & 60.3 \\
\hline No & 158 & 29.7 \\
\hline Student & 40 & 10.0 \\
\hline \multicolumn{3}{|l|}{ Religion } \\
\hline Catholic & 273 & 68.7 \\
\hline Evangelical & 81 & 20.4 \\
\hline Spiritualist & 11 & 2.7 \\
\hline Atheist & 5 & 1.2 \\
\hline Others & 27 & 6.8 \\
\hline Scholarity & 01 & 0.2 \\
\hline None & 32 & 8.0 \\
\hline Incomplete elementary school & 38 & 9.5 \\
\hline Complete primary education & 106 & 26.7 \\
\hline Incomplete high school & 116 & 29.2 \\
\hline Complete high school & 68 & 17.1 \\
\hline Incomplete higher education & 36 & 9.0 \\
\hline \multicolumn{3}{|l|}{ Civil status } \\
\hline $\begin{array}{l}\text { Married or in a stable } \\
\text { relationship }\end{array}$ & 246 & 61.9 \\
\hline Single & 120 & 30.2 \\
\hline Divorced & 28 & 7.0 \\
\hline Others & 3 & 0.7 \\
\hline \multicolumn{3}{|l|}{ Color/race } \\
\hline White & 239 & 60.2 \\
\hline Black & 50 & 12.5 \\
\hline Brown & 105 & 26.4 \\
\hline Indigenous & 3 & 0.7 \\
\hline
\end{tabular}

Analyzing the results of the scores (which can vary between 0 and 10 points) of the different domains of assessment of Primary Health Care, obtained through the PCATool instrument, it is observed in Table 2 that only in Domain $\mathrm{E}$ (Coordination Integration of (are) it was not possible to calculate the score for all research participants, as $31.99 \%$ indicated that they do not know/do not remember if they went to see any type of specialist or specialized service when they were being monitored.

It is noted that the highest average score among the eight domains evaluated is related to I (Family Guidance), followed by $\mathrm{E}$ (Coordination - Integration of Care), with averages of 5.86 and 4.89 points, respectively, highlighting it appears that none of the domains had an average score higher than the reference value of 6.66, established as the limit between high and low scores.12 On the other hand, the lowest averages refer to Domains $\mathrm{H}$ (Integrity - Services Provided) and J (Community Orientation ), with averages of 3.32 and 3.76 points, respectively.

Now considering the grouped scores, both for the essential domains ( $\mathrm{C}$ to $\mathrm{H}$ ) and for the derivatives ( $\mathrm{I}$ and $\mathrm{J})$, it is seen that the means were 4.28 and 4.81 points, respectively, while the score overall average was 4.42 points (Table 2 ).

Regarding some essential attributes and derivatives assessed by women as unsatisfactory (considering the cutoff criterion), Table 3 shows the average scores obtained. It is noteworthy that only 11 of the 81 items evaluated had mean scores above 6.6 points, the cutoff value used for satisfactory classification.

Among the items evaluated negatively, it is observed that in Domain C (First Contact Access), the item with the lowest average score was C6 ("When your reference service is closed on Saturday and Sunday and you get sick, does someone from that service see you on the same day?"), 0.74 points on a scale of 0 to 10 points, being the lowest among all the items evaluated and the only one below 1 point.

All items in Domains D (Longitudinality) and I (Family Orientation) had average scores above 3 points, while for Domains $E$ (Coordination - Integration of Care), F (Coordination - Information System) and J (Community Orientation) all mean scores were greater than 2 points.

On the other hand, for Domain G (Integrity - Available Services), the lowest average score was 1.56 points and refers to item G10 (Suture of a cut that requires stitches), while for Domain H (Completeness - Services Provided), was 1 point for item H3 (Advice on the use of seat belts or safe seats for children when riding in a car).

Table 2 - Minimum, maximum and average scores with standard deviation and coefficient of variation of the attributes and components of Primary Health Care, in the assessment of women of reproductive age of the Family Health Strategy in six municipalities of the 16th Regional Health ( $n=397$ ), north of the state of Paraná, Brazil, 2020

\begin{tabular}{|c|c|c|c|c|c|c|}
\hline Domain & $\mathbf{n}$ & Minimum & Maximum & Mean & SD & CV \\
\hline C - First Contact Access & 397 & 0.83 & 8.06 & 3.75 & 1.28 & $34.13 \%$ \\
\hline D - Longitudinality & 397 & 2.86 & 6.67 & 4.72 & 0.75 & $15.95 \%$ \\
\hline E - Coordination - Integration of Care & 270 & 2.08 & 8.75 & 4.89 & 1.16 & $23.72 \%$ \\
\hline F - Coordination - Information System & 397 & 0.00 & 8.89 & 4.45 & 1.55 & $34.83 \%$ \\
\hline G - Completeness - Available Services & 397 & 2.88 & 7.42 & 4.78 & 0.77 & $16.11 \%$ \\
\hline H - Completeness - Services Provided & 397 & 1.28 & 5.64 & 3.32 & 0.89 & $26.75 \%$ \\
\hline I - Family Orientation & 397 & 1.11 & 10.00 & 5.86 & 1.95 & $33.28 \%$ \\
\hline $\mathrm{J}$-Community Orientation & 397 & 1.11 & 7.22 & 3.76 & 1.26 & $33.51 \%$ \\
\hline Essential & 397 & 2.87 & 5.69 & 4.28 & 0.46 & $10.84 \%$ \\
\hline Derivative & 397 & 1.39 & 8.06 & 4.81 & 1.16 & $24.12 \%$ \\
\hline General & 397 & 3.18 & 6.28 & 4.42 & 0.45 & $10.23 \%$ \\
\hline
\end{tabular}

SD - standard deviation; CV - coefficient of variation. 
Table 3 - Description of the domains between the attributes that were negatively evaluated (below the cutoff criterion of 6.6 points) and that are priority for actions to improve Primary Health Care for women of reproductive age in six municipalities of the 16th Regional Health (n. =397), north of the state of Paraná, Brazil, 2020

\begin{tabular}{|c|c|c|}
\hline Domain & Item & $\begin{array}{l}\text { Mean } \\
\text { Score }\end{array}$ \\
\hline \multirow{12}{*}{$\begin{array}{l}\text { C - First Contact } \\
\text { Access }\end{array}$} & C1. Is your referral service open on Saturday or Sunday? & 3.59 \\
\hline & C2. Is your referral service open at least a few weekday nights until 8 pm? & 4.91 \\
\hline & C3. When your referral service is open and you get sick, does someone there see you on the same day? & 5.31 \\
\hline & C4. When your referral service is open, do you answer the phone if you need to? & 2.90 \\
\hline & C5. When your referral service is closed, where can you call when you get sick? & 4.16 \\
\hline & $\begin{array}{l}\text { C6. When your referral service is closed on Saturday and Sunday and you get sick, does someone from that service see you on the } \\
\text { same day? }\end{array}$ & 0.74 \\
\hline & C7. When your referral service is closed and you get sick overnight, does someone from that service see you that night? & 3.51 \\
\hline & C8. Is it easy to make an appointment for a review appointment at your referral service? & 5.66 \\
\hline & $\begin{array}{l}\text { C9. When you arrive at your referral service, do you have to wait more than } 30 \text { minutes to see the doctor or nurse (not counting } \\
\text { screening and reception?) }\end{array}$ & 3.03 \\
\hline & C10. Do you have to wait a long time at your referral service? & 3.12 \\
\hline & C11 - Is it difficult for you to get medical care from your referral service when you think it is necessary? & 3.73 \\
\hline & C12. When you have to go to your referral health service, do you have to miss work or school? & 4.31 \\
\hline \multirow{13}{*}{$\begin{array}{l}\text { D - } \\
\text { Longitudinality }\end{array}$} & D1. When you go to your referral service, is it the same doctor or nurse who sees you every time? & 4.33 \\
\hline & D3. Does your "doctor/nurse" answer your questions in a way you understand? & 5.32 \\
\hline & D4. If you have a question, can you call and speak to the doctor or nurse who knows you best? & 3.71 \\
\hline & D5. Does your "doctor/nurse" give you enough time to talk about your concerns or problems? & 6.14 \\
\hline & D6. Are you comfortable sharing your concerns or problems with your "doctor/nurse"? & 6.15 \\
\hline & D7. Does your "doctor/nurse" know you more as a person than just someone with a health problem? & 3.99 \\
\hline & D8. Does your "doctor/nurse" know who lives with you? & 3.80 \\
\hline & D9. Does your "doctor/nurse" know which issues are most important to you? & 4.33 \\
\hline & D10. Does your "doctor/nurse" know your complete medical history (medical history)? & 6.17 \\
\hline & D11. Does your "doctor/nurse"know about your job or job? & 3.91 \\
\hline & D12. Would your "doctor/nurse" know at all if you had problems getting or paying for medications you need? & 3.93 \\
\hline & D13. Does your "doctor/nurse" know about all the medications you are taking? & 4.09 \\
\hline & D14. Would you switch from your referral service to another health service if it was too easy to do? & 3.17 \\
\hline \multirow{5}{*}{$\begin{array}{l}\text { E-Coordination } \\
\text { - Integration of } \\
\text { Care }\end{array}$} & E3. Does your referral service know that you have made these consultations with this specialist or specialist service? & 5.54 \\
\hline & E4. Has your "doctor/nurse" discussed different services where you could be seen for this health problem with you? & 4.19 \\
\hline & E7. Does your referral service know the results of this consultation? & 3.94 \\
\hline & $\begin{array}{l}\text { E8. After you went to this specialist or specialist service, did your "doctor/nurse" talk to you about what happened during this } \\
\text { appointment? }\end{array}$ & 2.37 \\
\hline & $\begin{array}{l}\text { E9. Did your "doctor/nurse" seem interested in the quality of care you were given (asked you if you were well or poorly cared for by } \\
\text { this specialist or specialized service)? }\end{array}$ & 2.62 \\
\hline \multirow{3}{*}{$\begin{array}{l}\text { F-Coordination } \\
\text { - Information } \\
\text { System }\end{array}$} & $\begin{array}{l}\text { F1. When you go to your referral service, do you take any of the health records or care records you have received in the past? } \\
\text { (Exemplify if you do not understand "record": emergency care records, laboratory test results) }\end{array}$ & 2.51 \\
\hline & F2. When you go to your referral service, is your medical record (clinical history) always available at the appointment? & 6.31 \\
\hline & F3. Could you read (consult) your medical record/file if you wanted to in your referral service? & 4.52 \\
\hline \multirow{9}{*}{$\begin{array}{l}\text { G - } \\
\text { Completeness } \\
\text { - Available } \\
\text { Services }\end{array}$} & G1. Answers to questions about nutrition or diet. & 4.11 \\
\hline & G2. Check if your family can participate in any social assistance or social benefits programs. & 3.67 \\
\hline & G3. Nutritional supplementation program (eg, milk, food) & 2.69 \\
\hline & G6. Dental treatment & 6.35 \\
\hline & G8. Counseling or treatment for the harmful use of drugs (legal or illegal - e.g., alcohol, cocaine, sleeping pills) & 3.21 \\
\hline & G9. Counseling for mental health issues & 3.48 \\
\hline & G10. Suture of a cut that requires stitches & 1.56 \\
\hline & G11. Counseling and requesting anti-HIV testing & 3.50 \\
\hline & G12 Identification (some type of assessment) of hearing problems (to listen) & 2.44 \\
\hline
\end{tabular}




\begin{tabular}{|c|c|c|}
\hline Domain & Item & $\begin{array}{l}\text { Mean } \\
\text { Score }\end{array}$ \\
\hline \multirow{8}{*}{$\begin{array}{l}\text { G - } \\
\text { Completeness } \\
\text { - Available } \\
\text { Services }\end{array}$} & G13. Identification (some kind of assessment) of visual problems (to see) & 2.74 \\
\hline & G14. Placing a splint (e.g., for sprained ankle) & 3.98 \\
\hline & G15. wart removal & 3.09 \\
\hline & G17. Advice to stop smoking & 3.99 \\
\hline & G19. Ingrown toenail removal & 3.87 \\
\hline & G20. Advice on changes that occur with aging (eg, memory impairment, risk of falling) & 4.31 \\
\hline & G21. Guidance on home care for someone in your family, such as dressings, changing tubes, bathing in bed & 6.59 \\
\hline & $\begin{array}{l}\text { G22. Guidance on what to do if someone in your family is disabled and cannot make decisions about their health (organ } \\
\text { donation if someone in your family is unable to decide, in a state of coma for example) }\end{array}$ & 3.42 \\
\hline \multirow{13}{*}{$\begin{array}{l}\mathrm{H} \text { - } \\
\text { Completeness } \\
\text { - Services } \\
\text { Provided }\end{array}$} & H1. Advice on healthy eating or getting enough sleep & 3.07 \\
\hline & H2. Home Safety — How to Store Medicines Safely & 2.56 \\
\hline & H3. Advice on using a seatbelt or safe child seats when riding in a car & 1.00 \\
\hline & H4. Ways to Deal with Family Conflicts That Can Come Up from Time to Time & 2.06 \\
\hline & H5. Advice on Exercise Appropriate for You & 5.68 \\
\hline & H6. Blood Tests to Check Cholesterol Levels & 2.71 \\
\hline & H7. Check and discuss the medications you are taking & 6.47 \\
\hline & H8. Possible exposures to hazardous substances (e.g., ant/mouse poison, bleach) in your home, work, or neighborhood & 2.25 \\
\hline & H9. Asking if you have a firearm and providing advice on how to safely store it & 1.95 \\
\hline & H10. How to prevent burns & 3.40 \\
\hline & H11. How to prevent falls & 3.85 \\
\hline & H12. Just for Women: How to Prevent Osteoporosis or Brittle Bones & 2.79 \\
\hline & H13. Just for women: care for common menstruation or menopause problems & 5.41 \\
\hline \multirow[t]{2}{*}{$\begin{array}{l}\text { I- Family } \\
\text { Orientation }\end{array}$} & $\begin{array}{l}\text { 11. Does your "doctor/nurse" ask you about your ideas and opinions (about what you think) when planning treatment and care for } \\
\text { you or a family member? }\end{array}$ & 5.99 \\
\hline & 13. Would your "doctor/nurse" meet with members of your family if you felt it necessary? & 4.53 \\
\hline \multirow{5}{*}{$\begin{array}{l}\text { J-Community } \\
\text { Orientation }\end{array}$} & J2. Does your referral service know the important health problems in your neighborhood? & 4.36 \\
\hline & J3. Does your referral service listen to community opinions and ideas on how to improve health services? & 3.07 \\
\hline & J4. Do you survey patients to see if services are meeting all of people's needs? & 2.77 \\
\hline & J5. Do you conduct community surveys to identify health problems he should be aware of? & 2.60 \\
\hline & J6. Invite you and your family to participate in the Local Health Council (Management Council/Users Council)? & 2.51 \\
\hline
\end{tabular}

\section{DISCUSSION}

Women are the public that most seeks care in $\mathrm{PHC}^{(15)}$, and generally these services are related to treatments for preexisting chronic diseases, clinical symptoms of acute diseases, pregnancy, monitoring of children in medical care, vaccines and others, as well as collection of Pap smear test (preventive) ${ }^{(4,16)}$. However, the services in PHC in Brazil, despite the existence of public policies, are still characterized by curative care, with difficulties in carrying out actions to promote health and prevent diseases. The fragmentation and discontinuity in care is still noticeable, due to the insufficiency of network services and the inadequate articulation between the management and administration of services ${ }^{(4)}$.

This study evidenced the sociodemographic profile of women of reproductive age in six municipalities of the 16th Regional Health, located in the north of the state of Paraná. It was observed that women of reproductive age who most frequent $\mathrm{PHC}$ are aged between 21 and 40 years. Considering the age group, the data found corroborate a cross-sectional study on the prevalence of overweight and associated factors, carried out with 322 women of reproductive age living in the urban area of the municipality of Vitória, in the state of Pernambuco with 322 women in reproductive age in Northeast Brazil, in the same age group as the women in this study ${ }^{(16)}$. In a survey on gender, morbidity, access and use of health services in Brazil considering the National Household Sample Survey (PNAD) and the reason from the demand for health services for women in this age group, excluding births and prenatal consultations, it was shown that women seek more services in the PHC for the practice of routine exams, elective consultations, treatment of diseases and prevention of diseases such as cervical cancer; however, the main reason for the search is still the diseases ${ }^{(17)}$.

In the investigation of the quality of care for women of reproductive age in $\mathrm{PHC}$, the first attribute evaluated in this study was First Contact Access, which is subdivided into: "utilization component", which refers to the expansion and usefulness of 
health services; and "accessibility component", which identifies the location of the health facility close to the population for which it provides reception and care, the days and times accessible to care, the range of tolerance for elective and unscheduled consultations and the extent to which the population identifies the access opportunity ${ }^{(15)}$.

Although access is a fundamental characteristic of PHC services, it was observed that this component reached an average with a low score, a result that is comparable and observed in different studies $^{(15,17-18)}$. The low score related to accessibility may be linked to the fact that that most ESF teams in the PHC participating in the research work only on weekdays and business hours (7:00 am to 5:00 pm), in addition to not working at night or on weekends and not making prior appointments, except small urgencies.

Access is the way in which the user gets care at the first contact in the health unit in their territory ${ }^{(19)}$. The use of services covers all direct and indirect contact; thus, women of reproductive age have not been able to use the $\mathrm{PHC}$ services, which derives from the interaction between users and health professionals regarding the available services ${ }^{(19)}$. Access to the care network is essential for women to be able to reach the services and receive first-contact attention. It is with this attention in mind that municipal managers must organize the scope of services offered to this audience.

In the Longitudinality attribute, the aim was to assess the relationship that women have with health professionals in the cities studied, and the mean of this score was also low. Longitudinality allows professionals to know the health problems of users by following them over time. The results of this attribute are in accordance with the performance of First Contact Access in the Use dimension, which testifies in favor of the team, which may have difficulty in approaching women of reproductive age for inclusion and involvement in actions and services in $\mathrm{PHC}$ with the FHS teams ${ }^{(13,20)}$.

Nevertheless, a study carried out in a city in the interior of São Paulo, which aimed to assess organizational and performance characteristics, from the perspective of users, ensures that PHC workers must know their enrolled population and consider that, in order to establish a bond, it is essential to recognize users as people who speak, assess and crave attention and solving their health problems ${ }^{(20-21)}$.

In this study, the attribute Coordination, which is related to the integration of care, had a low score in this population of women. This attribute requires continuity of services offered to these women and that must be performed by PHC professionals; it is up to them to recognize and consider the referral problems, when essential, in order to ensure the integration of care at all levels of care and in the prevention of diseases ${ }^{(22)}$. The Information System component also obtained a low score, which should be a lot to the local organization of $\mathrm{PHC}^{14}$ and also to the fact that women are co-responsible for the individual care of the health records of other family members (spouse, children...).

In view of the aforementioned data, it can be said that the integration of the different levels of care for the coordination of care for women of reproductive age is still fragile, which compromises the strengthening of $\mathrm{PHC}$, health promotion, disease prevention, networking and the consolidation of the SUS ${ }^{(23)}$. It must be considered that the integration between services of different levels of complexity, in order to allow and guarantee access to both PHC and specialized care of high technological complexity, is still a constitutional responsibility. of the SUS ${ }^{(15)}$.

The Integrality attribute refers to the aggregation of services available and performed by the $\mathrm{PHC}$ to its users, covering promotion, prevention, cure and rehabilitation actions, in order to ensure comprehensive care ${ }^{(13-14,22)}$. Integrality aims to consider the care production practices that must be present in meeting the health needs of women - that is, the specific needs of women available in the health care network, with the appreciation of subjectivities, individualities, dimensioning of risks and vulnerabilities to which the women are exposed in their daily lives and in the social environment ${ }^{(9-10)}$.

The component Services Available for women of reproductive age achieved a low average score, a result that converged with an evaluation study of Primary Health Care carried out with physically challenged and non-disabled users in the state of São Paulo ${ }^{(12)}$. This component refers to services and/or guidelines that women and their families have available when they need it $^{(13-14)}$.

It is noteworthy that the services recognized as available are very common and usual in the FHS units linked to PHC, with preventive actions that must be implemented, aimed at women's health, and without interfering with the health promotion environment and the population assigned according to the diversity of their needs and priorities ${ }^{(15,17)}$.

Thus, the Services Provided component also achieved a low average score; this data identifies that actions aimed at preventing diseases and promoting health are still insufficient in the experience of women of reproductive age in PHC/FHS. It is important to highlight that the evaluation of the Services Provided is directed towards the actions and services used by the user or someone in her family, in an FHS unit ${ }^{(13)}$. Although the importance of Integrality is considered as a guarantee of the effectiveness of the PHC, the components related to this attribute had a lower than expected result, showing that there is still a lack of improvements in the services offered to these women and their families.

The comprehensiveness of care is linked to the reception, the way of creating a bond and also to autonomy ${ }^{(2)}$. This attribute is extremely important and depends on the redefinition of practices that value the subjectivities essential to the work of health teams and the individual needs of women, with the construction of possibilities for prioritized and user-centered care, having as a starting point any type of intervention ${ }^{(2,4)}$. In order to put into practice the attribute of comprehensiveness, it is necessary to rethink the practices and actions developed, leaving the comfort zone in relation to the discontinuity of care and curative practices, the lack of health promotion and disease prevention in public health services ${ }^{(4,23)}$.

In view of the assessment of the attributes of $\mathrm{PHC}$, the result of the essential scores showed weaknesses, with scores below the average, pointing to the need to renew practices and actions in the context of PHC. For this, it is essential to have technical and practical changes in health care $^{(24)}$, considering the population of women of reproductive age.

In the results of the derived attributes, the Family Orientation attribute also had a low average score, but even better than the others. This attribute considers family care as the fundamental element 
of $\mathrm{PHC}^{(13)}$. It is interrelated with the attribute of comprehensiveness in women's health care, considering that relationships within health actions become resolute and effective, as they contribute to autonomy and in family knowledge regarding the continuity of care necessary for women's health and in the search for the health service ${ }^{(15)}$. In studies carried out ${ }^{(15,17,24)}$ with other users on the quality of Primary Health Care, this attribute also had a score below the average, in line with the results of the present study.

Community Orientation is an attribute related to the perception of the health needs of individuals in each social context, which requires knowledge of the local social reality ${ }^{(13-14)}$. The mean score for this attribute was also low, although the population of women of reproductive age be the most assiduous in PHC. However, this audience should be heard more, because when the health problems in the community are known, it becomes possible to build epidemiological data and make available resources for improvements in $\mathrm{PHC}$ services ${ }^{(24)}$. The items in this attribute involve the care provided by home visit, investigations and analyzes on the health-disease process of the population and information on the life and health situation of these women and their families.

When evaluating the results of the scores of essential and derived attributes, it was noticed that the performance of the $\mathrm{PHC}$ was unsatisfactory in all the cities studied. Therefore, considering the assessment of attributes by women of reproductive age attended at health institutions, there were no significant differences regarding the type of $\mathrm{PHC}$ health unit.

\section{Study limitations}

As a limitation of the study, there is the restriction of the research to six municipalities of a Regional Health located in the north of the state of Paraná; and the population of women of reproductive age was evaluated exclusively. Such municipalities may have deficiencies and insufficiency of the services offered in the PHC; in addition, a more critical view could have been obtained from health professionals and managers. It is worth noting that the PCATool has some specific items for the female population, but most of them are related to the assessment of the general population. Nevertheless, it is considered a relevant instrument, as it analyzes the essential and derived attributes, as well as assesses the quality of services offered in the PHC that should and can be worked with the public of women of reproductive age.

\section{Contributions to the field of nursing}

The assessment of PHC attributes provides contributions to the area of health, nursing, and public policies as it points out possibilities in the work of nurses in PHC/FHS to promote improvements in the quality of services offered to women of reproductive age, in addition to individual and collective actions that can be offered to this population. Thus, these hypotheses can support professional improvement processes to support the construction, development, and implementation of these actions, to improve the performance of $\mathrm{PHC}$ services in comprehensive care to women's health in all vital cycles.

Despite obstacles in the face of different managements and fragmentation of $\mathrm{PHC}$ services for an adequate and resolute care in the integral health care of women of reproductive age, it is believed in the potential of the professional nurse with the multidisciplinary team in the planning and execution of adjacent actions that enable and encourage preventive care and health promotion in accordance with the attributes of PHC.

\section{CONCLUSIONS}

The PHC attributes, as a whole, reached an average score below 6.6, with low scores being identified (in essential, derived and general attributes) for $\mathrm{PHC}$ services in the cities studied and implemented through the FHS. Thus, weaknesses were identified regarding the presence and extension of all attributes, evidenced in the unsatisfactory assessment of women of reproductive age regarding the performance of $\mathrm{PHC}$.

It is important to highlight that these women are young, capable of health promotion, disease prevention and comprehensive care as recommended in public policies for women's health within the $\mathrm{PHC}$ services. Thus, there are still challenges to be overcome considering the demand for care, in the expectation of implementing the ESF as a method of reorganizing the $\mathrm{PHC}$, ensuring comprehensive care with guaranteed universality and quality to the population of women of reproductive age. It is worth stressing the importance of public policies not only being organized, but implemented with quality and effectively by $\mathrm{PHC}$ professionals, so that their goals are achieved, promoting improvements in the health conditions of women and different population groups.

\section{REFERENCES}

1. Araújo WRM, Queiroz RCS, Rocha TAH, Silva NC, Thumé E, Tomasi E, et al. Structure and work process in primary care and hospitalizations for sensitive conditions. Rev Saude Publica. 2017;51(75):1-12. https://doi.org/10.11606/S1518-8787.20170510070331

2. Oliveira MAC, Pereira IC. Primary Health Care essential attributes and the Family Health Strategy. Rev Bras Enferm. 2013;66(esp):158-64. https://doi.org/10.1590/S0034-71672013000700020

3. Mendes EV. A construção social da atenção primária à saúde. Brasília: Conselho Nacional de Secretários de Saúde - CONASS [Internet] 2015[cited 2020 Sep 10]. Available from: https://www.conass.org.br/biblioteca/pdf/A-CONSTR-SOC-ATEN-PRIM-SAUDE.pdf

4. Almeida MHM, Pacheco S, Krebs S, Oliveira AM, Samelli A, Molini-Avejonas DR, et al. Primary health care assessment by users with and without disabilities CoDAS 2017;29(5):e20160225. https://doi.org/10.1590/2317-1782/20172016225

5. Mendes CRA. Attention to women's health in primary care: potential and limits. Ensaios Cienc Biol Agrar Saúde. 2016;20(2):65-72. https:// doi.org/10.17921/1415-6938.2016v20n2p65-72 
6. Lima EFA, Sousa Al, Primo CC, Leite FMC, Lima RCD, Maciel ELN. An assessment of primary care attributes from the perspective of female health care users. Rev Latino-Am Enfermagem. 2015;23(3):553-9. https://doi.org/10.1590/0104-1169.0496.2587

7. Ministério da Saúde (BR). Secretaria de Políticas para as Mulheres - SPM, Monitoramento e Acompanhamento da Política Nacional de Atenção Integral à Saúde da Mulher (PNAISM) e do Plano Nacional de Políticas para as Mulheres 2013-2015 (PNPM) [Internet]. 2016[cited 2020 Sep 10]. Available from: https://www.gov.br/mdh/pt-br/navegue-por-temas/politicas-para-mulheres/arquivo/central-deconteudos/ publicacoes/publicacoes/2015/pnaism_pnpm-versaoweb.pdf

8. Instituto Brasileiro de Geografia e Estatistica (IBGE). Pesquisa Nacional de Saúde-2019: informações sobre domicílios, acesso e utilização dos serviços de saúde- Brasil, grandes regiões e unidades da Federação[Internet]. Rio de Janeiro: IBGE. 2020[cited 2021 Jan 10]. Available from: https://biblioteca.ibge.gov.br/visualizacao/livros/liv101748.pdf

9. Branco JGO, Vieira LJES, Brilhante AVM, Batista MH. Weaknesses in the work process in Health Care for Women in situations of sexual violence. Ciên Saúde Coletiva. 2019;25(5):1877-86. https://doi.org/10.1590/1413-81232020255.34732019

10. Guareschi NMF. Políticas públicas de saúde da mulher: a integralidade em questão. Rev Estud Fem. 2009;17(1):31-48. https://doi. org/10.1590/S0104-026X2009000100003

11. Paiva AAN, Caetano R. Evaluation of the implementation of sexual and reproductive health actions in Primary Care: scope review. Esc Anna Nery. 2020;24(1):e20190142. https://doi.org/10.1590/2177-9465-ean-2019-0142

12. Coutinho SED, Reichert APS, Nogueira JA, Toso BRGO, Collet N. Health assessment: processual and structural dimension of child health in primary care. Saúde Debate. 2020;44(124). https://doi.org/10.1590/0103-1104202012408

13. Ministério da Saúde (BR). Manual do instrumento de avaliação da atenção primária à saúde: Primary Care Assessment Tool pcaTool[Internet]. 2010[cited 2019 Jul 10]. Available from: http://bvsms.saude.gov.br/bvs/publicacoes/manual_avaliacao_pcaTool_brasil.pdf

14. Ministério da Saúde (BR). Manual do instrumento de avaliação da atenção primária à saúde: Primary Care Assessment Tool pcaTool [Internet]. 2020 [cited 2021 Jan 10]. Available from: https://www.conasems.org.br/wp-content/uploads/2020/05/Pcatool_2020.pdf

15. Silva AN, Silva SA, Silva ARV, Araújo TME, Rebouças CBA, Nogueira LT. Primary care assessment from a male population perspective. Rev Bras Enferm. 2018;71(2):236-43. https://doi.org/10.1590/0034-7167-2016-0651

16. Pinheiro MM, Oliveira JS, Leal VS, Lira PIC, Souza NP, Campos FACS. Prevalence of overweight and associate factors in women in reproductive age in Northeast Brazil. Rev Nutr. 2016;29(5):679-89. https://doi.org/10.1590/1678-98652016000500006

17. Vieira Sá LYBA. A Avaliação da Atenção Primária: um olhar preliminar através do PCATool em Manaus (AMAZONAS). APS Rev. 2019;1(2):98111. https://doi.org/10.14295/aps.v1i2.27

18. Silva AS, Baitelo TC, Fraco LA. Assessment of primary health care: health professionals' perspective. Rev Latino-Am Enfermagem. 2015;23(5):979-87. https://doi.org/10.1590/S0080-623420140000600018

19. Lima EFA, Sousa Al, Primo CC, Leite FMC, Lima RCD, Maciel ELN. An assessment of primary care attributes from the perspective of female healthcare users. Rev Latino-Am. Enfermagem. 2015;23(3):553- 9. https://doi.org/10.1590/0104-1169.0496.2587

20. Pereira MJB, Abrahão-Curvo P, Fortuna CM, Coutinho SS, Queluz MC, Campos LVO, et al. Evaluation of organizational and performance features in a Basic Health Unit. Rev Gaúcha Enferm. 2011;32(1):48-55. https://doi.org/10.1590/S1983-14472011000100006

21. Starfield B. Atenção Primária: equilíbrio entre necessidades de saúde, serviços e tecnologias[Internet]. Brasília, UNESCO; 2002. 726p. [cited 2017 Feb 20]. Available from: http://bvsms.saude.gov.br/bvs/publicacoes/atencao_primaria_p1.pdf

22. Reichert APS, Leônico ABA, Toso BRG, Santos NCCB, Vaz EMC, Colle N. Family and community orientation in children's primary healthcare. Ciên Saúde Coletiva. 2016;21(1):119-27. https://doi.org/10.1590/1413-81232015211.05682014

23. Pinheiro RS, Viacava F, Travassos C, Brito AS. Gender, morbidity, access and utilization of health services in Brazil. Ciên Saúde Coletiva. 2002;7(4):687-707. https://doi.org/10.1590/S1413-81232002000400007

24. Silva RAS, Oliver FC. A interface das práticas de terapeutas ocupacionais com os atributos da atenção primária à saúde. Cad Bras Terap Ocup. 2020;28(3):784-808. https://doi.org/10.4322/2526-8910.ctoAO2029 